\title{
Asymbiotic germination in three Chloraea species (Orchidaceae) from Chile
}

\section{Germinación asimbiótica en tres especies de Chloraea (Orchidaceae) de Chile}

\author{
Guillermo Pereira ${ }^{1}$, Verónica Albornoz ${ }^{1}$, Christian Romero ${ }^{1}$, Sebastián Lara ${ }^{3}$ Manuel Sánchez- \\ Olate ${ }^{2}$, Darcy Ríos ${ }^{2} \&$ Cristian Atala ${ }^{3 *}$
}

${ }^{1}$ Laboratorio Biotecnología de Hongos, Campus Los Ángeles, Universidad de Concepción, Casilla 234, Los Ángeles, Chile. 'Laboratorio Cultivo de Tejidos Vegetales, Facultad de Ciencias Forestales, Universidad de Concepción, Casilla 160-C, Concepción, Chile.

${ }^{3}$ Laboratorio de Anatomía y Ecología de Plantas. Instituto de Biología, Facultad de Ciencias, Pontificia Universidad Católica de Valparaíso, Campus Curauma, Avenida Universidad 330, Valparaíso, Chile.

*cristian.atala@pucv.cl

\begin{abstract}
Orchids require symbiotic fungi and/or specific conditions to germinate. Asymbiotic techniques have been shown successful for orchid germination. In Chile, Chloraea include many endemic, and potentially ornamental, terrestrial orchid species. In this study, individuals of Chloraea crispa, C. gavilu and C. virescens were manually autopollinated. The resulting capsules were sterilized and seeds were aseptically obtained. We evaluated asymbiotic germination in: Agar Water (AW), Knudson $\mathrm{C}(\mathrm{KC})$, Banana Culture Media (CMB), Tomato Culture Media (CMT), Malmgren Modified (MM), Murashige and Skoog (MS), and MS modified (MS1/2). Seeds were incubated in the dark at $24 \pm 1{ }^{\circ} \mathrm{C}$ for 2 weeks. Then they were put in $16 / 8 \mathrm{~h}$ light/dark cycles for 14 weeks. We registered germination and embryo development in the different culture media. After 8 weeks, all tested Chloraea species germinated in most culture media. After 16 weeks, embryos in MM showed an evident shoot. In AW only the pre-germination stage was achieved. In C. gavilu germination was over 90\% in MM, CMT, and $\mathrm{CMB}$. In $\mathrm{KC}$, a lower germination was obtained in all tested species compared to the other culture media, except for AW. Asymbiotic germination of endemic Chilean orchids could be a viable strategy for their conservation and propagation as ornamental species.
\end{abstract}

KEYwoRDs: Terrestrial orchids, endemic species, in vitro germination, culture media, orchid propagation, asymbiotic germination.

\section{RESUMEN}

Las orquídeas requieren hongos simbióticos y/o condiciones específicas para germinar. Las técnicas asimbióticas se han mostrado efectivas para la germinación de orquídeas. En Chile Chloraea incluye muchas especies de orquídeas endémicas terrestres y con potencial ornamental. En este estudio, individuos de Chloraea crispa, C. gavilu y C. virescens fueron autopolinizados manualmente. Las cápsulas resultantes fueron esterilizadas y se obtuvieron las semillas asépticamente. Se evaluó la germinación asimbiótica en: Agar Agua (AW), Knudson C (KC), Medio de Cultivo Banana (CMB), Medio de Cultivo Tomate (CMT), Malmgren Modified (MM), Murashige y Skoog (MS), y en MS modificado (MS1/2). Las semillas se incubaron en oscuridad a $24 \pm 1{ }^{\circ} \mathrm{C}$ por 2 semanas. Luego fueron puestas en ciclos de $16 / 8 \mathrm{~h} \mathrm{luz} /$ oscuridad por 14 semanas. Se registró la germinación y desarrollo del embrión en los diferentes medios de cultivo. Luego de 8 semanas, todas las especies de Chloraea estudiadas germinaron en la mayoría de los medios de cultivo. Luego de 16 semanas, los embriones en MM mostraron un brote evidente. En AW sólo se alcanzó la etapa de pregerminación. En C. gavilu, la germinación fue sobre el $90 \%$ en MM, CMT y CMB. En KC se obtuvo una menor germinación en todas las especies comparado con los otros medios de cultivo, excepto AW. La germinación asimbiótica de orquídeas endémicas de Chile puede ser una estrategia viable para su conservación y propagación como especies ornamentales.

Palabras clave: Orquídeas terrestres, especies endémicas, germinación in vitro, medios de cultivo, propagación de orquídeas, germinación asimbiótica. 


\section{INTRODUCTION}

Orchids are highly valued plant species, mainly due to their applications as ornamental plants, bioresources for perfumes and medicines, and condiments (Dearnaley 2007, Dearnaley et al. 2012, Abraham et al. 2012). Most of these species are from the tropics, and are cultivated and propagated in controlled conditions (Stenberg \& Kane 1998, Kauth et al. 2006). In the tropics, orchid species are usually epiphytic, with only $20-30 \%$ of the species terrestrial, and are important elements of the epiphytic diversity of tropical forests, forming many complex interactions with insects and fungi (Heywood et al. 2007). However, other Orchidaceae, particularly temperate species which are commonly terrestrial, are understudied and many are endangered due to habitat loss and other anthropic effects such as fires and cattle damage (Atala et al. 2017). Orchid seeds are very small and lack an endosperm, which is the food reserve of the typical seed (Heywood et al. 2007, Paudel et al. 2012). In the soil, orchid seeds associate with fungal partners that induce germination and promote embryo growth, supplying the required nutrients to the embryo (Valadares et al. 2012, Rasmussen et al. 2015). Thus, propagating orchids through seeds may require the presence of specific fungi or specific culture media that can replace the nutrient supply given by such fungi (Otero \& Bayman 2009). This method of propagation can be very effective since orchids produce large amount of seeds and genetic variation is preserved, compared to cloning or similar techniques.

Asymbiotic seed germination (i.e. without fungal inoculation) has been shown to be a proper tool for the production of plantlets of several orchid species for commercial and conservation purposes (Yamazaki \& Miyoshi 2006, Dutra et al. 2008, Kauth et al. 2006, 2008, Stewart \& Kane 2010, Pereira et al. 2015). Knudson (1922, 1946) was the first to demonstrate that orchid seed could be germinated in vitro on a defined nutrient medium supplemented with a simple carbohydrate source. Other culture media with varied carbon sources have been tried for orchid germination such as tomato culture medium, banana culture medium, MS, among others (Pereira et al. 2015). These media can have different results depending on the orchid species (Paul et al. 2011, Pereira et al. 2015), suggesting intrinsic differences in nutrient requirements for different species. It has also been suggested that particular species may have different limiting factors for germination and seedling early growth (Rasmussen et al. 2015). These limitations can include the presence of specific fungi in the soil (Dixon 1991, Otero \& Bayman 2009, Thakur \& Dongarwar 2013) or abiotic conditions, that can ultimately affect regeneration and can result in local extinction of some populations if conditions change over time, especially considering that orchid plants can be very long-lived (Pedersen et al. 2012, Romero 2012, Rasmussen et al. 2015). Thus, laboratory technics for orchid propagation can be very helpful for conservation of rare or endangered orchid species.

Asymbiotic germination can be more effective than symbiotic germination for several reasons; 1) it does not require the isolation and identification of the mycobiont of the target orchid species. 2) It allows for more controlled, aseptic conditions, resulting in less overall contamination (Johnson et al. 2007, Aggarwal \& Zettler 2010, Abraham et al. 2012). 3) In symbiotic germination, the seeds inoculated with the mycorrhizic fungi can be completely covered with the fungal hyphae, making difficult the evaluation of germination and embryo development (personal observation), sometimes requiring a change in the culture media, increasing the risk of contamination. However, it is likely that further plant development and/or re-introduction of plants in the field could require fungal partners to enhance survival (Otero \& Bayman 2009, Thakur \& Dongarwar 2013, Pereira et al. 2015), especially considering that adult plants of some Chilean Chloraea have been found symbiotically associated with fungal partners in the field (Pereira et al. 2014, Atala et al. 2015).

In Chile there are 7 terrestrial orchid genera including 49 to 63 species (Lehnebach 2003, Novoa et al. 2006, Zuloaga et al. 2008), this variation in species number reflecting the poor taxonomic knowledge of the group. Chloraea is the most diverse genus in Chile and includes 29 species (Lehnebach 2003), some of which are considered endangered and most are not properly evaluated (Correa 1969, Novoa et al. 2006, Elórtegui \& Novoa 2009, Romero 2012). Moreover, Chile is considered the center of diversity of the genus (Bernhardt 1995). Chloraea species occur in Chile in diverse environments, growing in the understory of native forests to open and highly disturbed sites (Reiche 1910, Correa 1969, Romero 2012). Some Chloraea species, such as Chloraea gavilu Lindl., are found between Valparaíso ( 32 $\left.{ }^{\circ} \mathrm{S}\right)$ and Araucanía ( 39 $\left.{ }^{\circ} \mathrm{S}\right)$ Regions, while other species such as Chloraea crispa Lindl., have very narrow distribution, growing mostly in Bío-Bío Region between 36 to $38^{\circ} \mathrm{S}$ (Novoa et al. 2006, Elórtegui \& Novoa 2009). Chloraea crispa and C. gavilu are endemic to Chile, and $C$. virescens (Willd.) Lindl. (syn: C. piquichen (Lam.) Lindl.) is a native Chilean species that grows in Chile from 36 to $41{ }^{\circ} \mathrm{S}$ (Novoa et al. 2006, Elórtegui \& Novoa 2009, Novoa et al. 2015). All three species have high ornamental potential (Fig. 1A, B, C) and, to our knowledge, have not been reproduced asymbiotically (or by other means) before.

The aim of this study is to asymbiotically germinate the seeds of Chloraea crispa, C. gavilu, and C. virescens, and to evaluate embryo development of these species using different culture media. If successful, this technique could be a viable alternative for plant propagation to be used with commercial or conservation purposes. A previous study on a rare terrestrial orchid reported that in vitro germination can be a successful tool for orchid conservation (Stewart \& Kane 2006). 


\section{MATERIALS AND METHODS}

Plant Collection And SEed PRODUCTION

Individuals of three Chloraea species (C. crispa, C. gavilu, and $C$. virescens) were collected from natural populations located in Central-South Chile in late spring 2014-summer 2015 (November 2014-January 2015). C. crispa plants were collected close to the town of Quilleco, Bío-Bío Region ( $37^{\circ} 24^{\prime} 46.81^{\prime} \mathrm{S}, 72^{\circ} 1$ ' 8.22" W). C. gavilu individuals were collected in a road close to the town of Yumbel, Bío-Bío Region (36 59' 54.93” S, 72 34' 24.10" W). Lastly, C. virescens plants were collected in Pucón (Chilean city) aerodrome, Araucanía Region (39 $17^{\circ}$ ' 40.34" S, 71 ${ }^{\circ} 54^{\prime} 25.49^{\prime}$ 'W). The species was identified by its distinctive floral morphology following Novoa et al. (2006) and Elórtegui \& Novoa (2009). Collected plants were transplanted to $2000 \mathrm{~mL}$ plastic pots and put in a greenhouse at Universidad de Concepción, Campus Los Ángeles ( $37^{\circ} 28^{\prime} 20.33^{\prime}$ S S, 72 $20^{\circ} 45.50^{\prime}$ W). In the same season, it was conducted manual autopollination (Fig 1D) in 4 flowers per plant (4 plants per species). Previous to the dehiscence, capsules were taken (Fig. 1E) and the surface immediately sterilized with ethanol $98 \%$ and flamed under laminar flow chamber to avoid contamination. Capsules were then open and seeds were collected and used in the experiment described below.

ASYMBIOTIC GERMINATION

Seven culture media were used in the asymbiotic seed germination (Table 1): agar water (AW), banana culture medium (CMB; Barbery \& Molares 2011), tomato culture medium (CMT; Barbery \& Molares 2011), Knudson C (KC; Knudson 1946, Arditti 1982), Malmgren Modified Terrestrial Orchid Medium (MM; Malmgren 1996), Murashige \& Skoog medium (MS; Murashige \& Skoog 1962) and MS modified (MS1/2). All media were sterilized in an autoclave at $121{ }^{\circ} \mathrm{C}$ and 1 atm for $20 \mathrm{~min}$ and then poured into $40 \mathrm{~mm}$-diameter Petri dishes in a laminar flow chamber. Once all media were prepared, $\mathrm{pH}$ was adjusted to 5.8. Four plates (replicates) per culture media were used (four plates $\times$ seven culture media $=28$ plates total). Each plate contained at least 200 seeds. Petri dishes containing media and seeds were put in an incubator at $24 \pm 1{ }^{\circ} \mathrm{C}$ in the dark. After two weeks, seed developmental stage was evaluated (see Table 2, adapted from Yamazaki \& Miyochi 2006). Seeds were then put for four weeks in a growth chamber at $20 \pm 1{ }^{\circ} \mathrm{C}$ with a photoperiod of 16/8-hours light/ dark (light: $70 \mu \mathrm{mol} \mathrm{m} \mathrm{m}^{-2} \mathrm{~s}^{-1}$ ). Germination percentage was determined by counting the number of germinated seeds in all Petri dishes divided by total viable seeds. Seed viability was previously determined by the tetrazolium test (data not shown). Germination was achieved when the embryo emerged from the seed coat (stage 2 in Table 2).

Data ANALYSIS

The software Statistica 6.0 (StatSoft Inc., Tulsa, OK, USA) was used for the statistical analyses. Germination percentage was arcsine-transformed to normalize the data. One-way ANOVA with culture media as a fixed factor was used to determine differences in germination percentage between treatments followed by a posteriori Tukey Test. This was done for each orchid species separately.

\section{RESULTS}

Floral traits confirmed the identity of the studied species (Fig. 1A-C). After two weeks of the beginning of the experiment, seeds of some of the tested Chloraea species germinated in CMT, MM and CMB culture media (Fig. 2A). After eight weeks of incubation, embryos of all tested Chloraea species reached stage 3 (protocorm stage) in CMT and MM media (Fig 2B). Also, only C. gavilu seeds reached stage 3 in CMB. MS medium resulted in embryo development to stage 3 only in $C$. virescens. At 16 weeks after the beginning of the experiment, embryos of all species in MM medium reached the highest development, evidencing a distinct shoot (Shoot stage, Fig 1I, Fig. 2C), stage that is previous to true leaf initiation. Additionally, stage 4 (Rhizoid stage, Fig. 1H) was reached in all species in CMT and only in C. gavilu and $C$ virescens in MS medium. Plants in AW showed poor development and only reaches stage 1 (pre-germination stage, Fig. 2C).

The three tested Chloraea species showed differences in seed germination in the different culture media tested in our study (one-way ANOVA, $p<0.001$ for each species separately). Maximal germination in Chloraea crispa was obtained in CMT (close to $85 \%$ ), followed by MM and $\mathrm{CMB}$ with $\sim 70 \%$ germination (Fig. 3A), differing significantly from MS and KC (Tukey test, $p<0.05$ ). $C$. gavilu was the species with highest seed germination, reaching over 90\% in MM, CMT, and CMB (Fig. 3B). In this species germination was significantly higher in $\mathrm{MM}$ compared to $\mathrm{KC}$, and in $\mathrm{CMT}$ and $\mathrm{CMB}$ compared to $\mathrm{KC}$ (Tukey test, $p<0.05$ ). In $C$. virescens the best results were obtained in $\mathrm{MM}$ and $\mathrm{CMB}$ where germination reached over 85\% (Fig. 3C), being significantly higher than in CMB, MS, MS1/2, and KC (Tukey test, $p<0.05$ ). For all tested species, AW culture media did not allowed seed germination (Fig. 3A-C). 

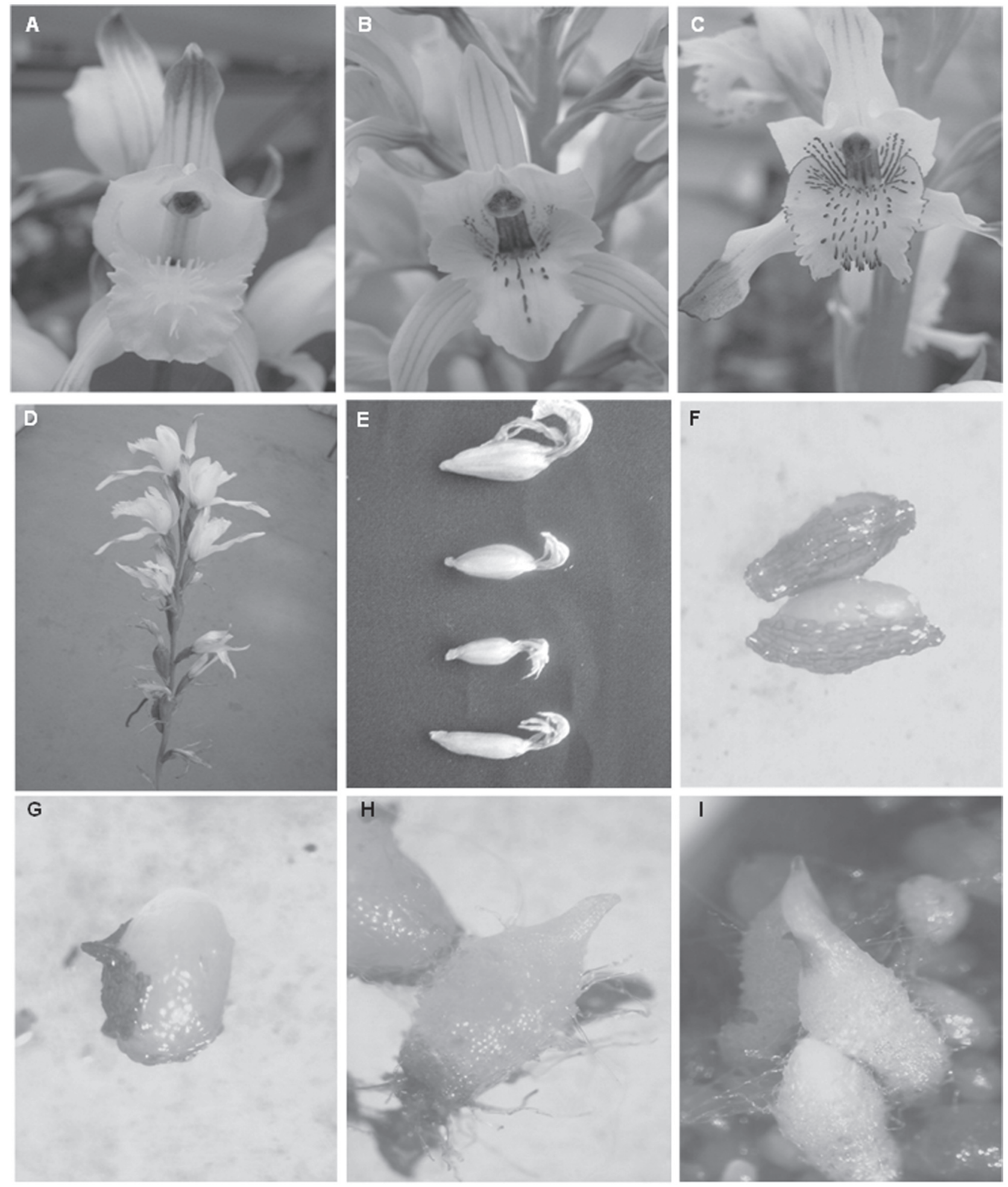

Figure 1. Images of the studied species. A) C. crispa. B) C. gavilu. C) C. virescens. D) Capsules forming after manual pollination. E) Mature capsules. F) Embryos breaking the seed coat. G) Protocorm. H) Protocorm with rhizoids. I) Protocorm with evident apical shoot. / Fotografías de las especies estudiadas. A) C. crispa. B) C. gavilu. C) C. virescens. D) Cápsulas formadas luego de la polinización manual. E) Cápsulas maduras. F) Embriones rompiendo la testa. G) Protocormo. H) Protocormo con rizoides. I) Protocormo evidenciando brote apical. 
Asymbiotic germination in three Chilean Chloraea: Pereira, G. et al.

TABLE 1. Comparative composition of culture media used for asymbiotic seed germination of three Chloraea species. AW: Agar Water. CMB: Banana Culture Medium. CMT: Tomato Culture Medium. KC: Knudson C. MM: Malmgren modified terrestrial orchid medium. MS: Murashige and Skoog, and MS1/2: MS modified. / Composición comparativa de los medios de cultivo usados para la germinación asimbiótica de semillas de tres especies de Chloraea. AW: Agar Agua. CMB: Medio de Cultivo Banana. CMT: Medio de Cultivo Tomate. KC: Knudson C. MM: Medio Malmgren modificado para orquídeas terrestres. MS: Murashige y Skoog, y MS1/2: MS modificado.

\begin{tabular}{|c|c|c|c|c|c|c|c|}
\hline & $\mathrm{KC}$ & MM & CMB & CMT & AW & MS & $\mathrm{MS} 1 / 2$ \\
\hline \multicolumn{8}{|l|}{ Macronutrients (mg/L) } \\
\hline$\left(\mathrm{NH}_{4}\right)_{2} \mathrm{SO}_{4}$ & 500 & & & & & & \\
\hline$\left(\mathrm{NH}_{4}\right)\left(\mathrm{NO}_{3}\right)$ & & & & & & 1650 & 825 \\
\hline $\mathrm{Ca}\left(\mathrm{NO}_{3}\right)_{2} \cdot 4 \mathrm{H}_{2} \mathrm{O}$ & 1000 & & & & & & \\
\hline $\mathrm{MgSO}_{4} \cdot 7 \mathrm{H}_{2} \mathrm{O}$ & 250 & & & & & & \\
\hline $\mathrm{KH}_{2} \mathrm{PO}_{4}$ & 250 & 75 & & & & 170 & 85 \\
\hline $\mathrm{KNO}_{3}$ & & & & & & 1900 & 950 \\
\hline $\mathrm{KI}$ & & & & & & 0.83 & 0.415 \\
\hline $\mathrm{CaCl}_{2}$ & & & & & & 332.2 & 166.1 \\
\hline $\mathrm{Ca}_{3}\left(\mathrm{PO}_{4}\right)_{2}$ & & 75 & & & & & \\
\hline $\mathrm{MgSO}_{4}$ & & 97.69 & & & & 180.7 & 90.35 \\
\hline $\mathrm{Na}_{2}$ EDTA $\cdot 2 \mathrm{H}_{2} \mathrm{O}$ & & 75 & & & & 37.26 & 18.63 \\
\hline \multicolumn{8}{|l|}{ Micronutrients (mg/L) } \\
\hline $\mathrm{MeSO}_{4} \cdot 7 \mathrm{H}_{2} \mathrm{O}$ & 25 & & & & & & \\
\hline $\mathrm{MnSO}_{4} \cdot 4 \mathrm{H}_{2} \mathrm{O}$ & 7.5 & & & & & & \\
\hline $\mathrm{MnSO}_{4} \cdot \mathrm{H}_{2} \mathrm{O}$ & & 1.54 & & & & 16.9 & 8.45 \\
\hline $\mathrm{H}_{3} \mathrm{BO}_{3}$ & 0.0560 & & & & & 6.2 & 3.1 \\
\hline $\mathrm{CuSO}_{4} \cdot 5 \mathrm{H}_{2} \mathrm{O}$ & 0.0624 & & & & & 0.025 & 0.0125 \\
\hline $\mathrm{MoO}_{3}$ & 0.0160 & & & & & & \\
\hline $\mathrm{MoO}_{4} \mathrm{Na}_{2} \cdot 2 \mathrm{H}_{2} \mathrm{O}$ & & & & & & 0.25 & 0.125 \\
\hline $\mathrm{ZnSO}_{4} \cdot 7 \mathrm{H}_{2} \mathrm{O}$ & 0.3310 & & & & & 8.6 & 4.3 \\
\hline $\mathrm{FeSO}_{4} \cdot 7 \mathrm{H}_{2} \mathrm{O}$ & & 27.8 & & & & 27.8 & 13.9 \\
\hline $\mathrm{CoCl}_{2} \cdot 6 \mathrm{H}_{2} \mathrm{O}$ & & & & & & 0.025 & 0.0125 \\
\hline \multicolumn{8}{|l|}{ Others $(\mathrm{mg} / \mathrm{L})$} \\
\hline Ripe banana (pulp) & & & 100000 & & & & \\
\hline Ripe tomato (pulp) & & & & 100000 & & & \\
\hline Yeast extract & & 1000 & & & & & \\
\hline Pineapple powder & & 20000 & & & & & \\
\hline D-Biotin & & 0.05 & & & & & \\
\hline $\begin{array}{l}\text { Casein, Enzymatic } \\
\text { Hydrolysate }\end{array}$ & & 400 & & & & & \\
\hline Folic acid & & 0.5 & & & & & \\
\hline Glycine (free base) & & 2 & & & & 2.0 & 1.0 \\
\hline Pyridoxine & & 5 & & & & 0.5 & 0.25 \\
\hline myo-Inositol & & 100 & & & & 100 & 50 \\
\hline Nicotinic acid (free acid) & & 5 & & & & 0.5 & 0.25 \\
\hline Thiamine & & 10 & 1200 & 1200 & & 0.1 & 0.05 \\
\hline Thidiazuron (TDZ) & & 0.1 & & & & & \\
\hline Sucrose & 20000 & 10000 & 15000 & 15000 & & 3000 & 3000 \\
\hline Agar & 10000 & 7000 & 10000 & 10000 & 10000 & 7000 & 7000 \\
\hline Activated charcoal & & 1000 & & & & & \\
\hline Deionized water $(\mathrm{mL})$ & 1000 & 1000 & 1000 & 1000 & 1000 & 1000 & 1000 \\
\hline
\end{tabular}


TABLE 2. Developmental stages of terrestrial orchid seeds (modified from Yamazaki \& Miyoshi 2006). / Estados de desarrollo de semillas de orquídeas terrestres (modificado de Yamazaki \& Miyoshi 2006).

\begin{tabular}{cl}
\hline STAGE & \multicolumn{1}{c}{ DESCRIPTION } \\
\hline 0 & No germination stage. No growth of embryo occurs. \\
1 & Pre germination stage. Embryo swells to fill the seed coat. \\
2 & Germination stage. Embryo emerges from the seed coat. \\
4 & Protocorm stage. Embryo is completely discharged from the seed coat. \\
5 & Rhizoid stage. Rhizoids are formed on the protocorm surface. \\
\hline
\end{tabular}

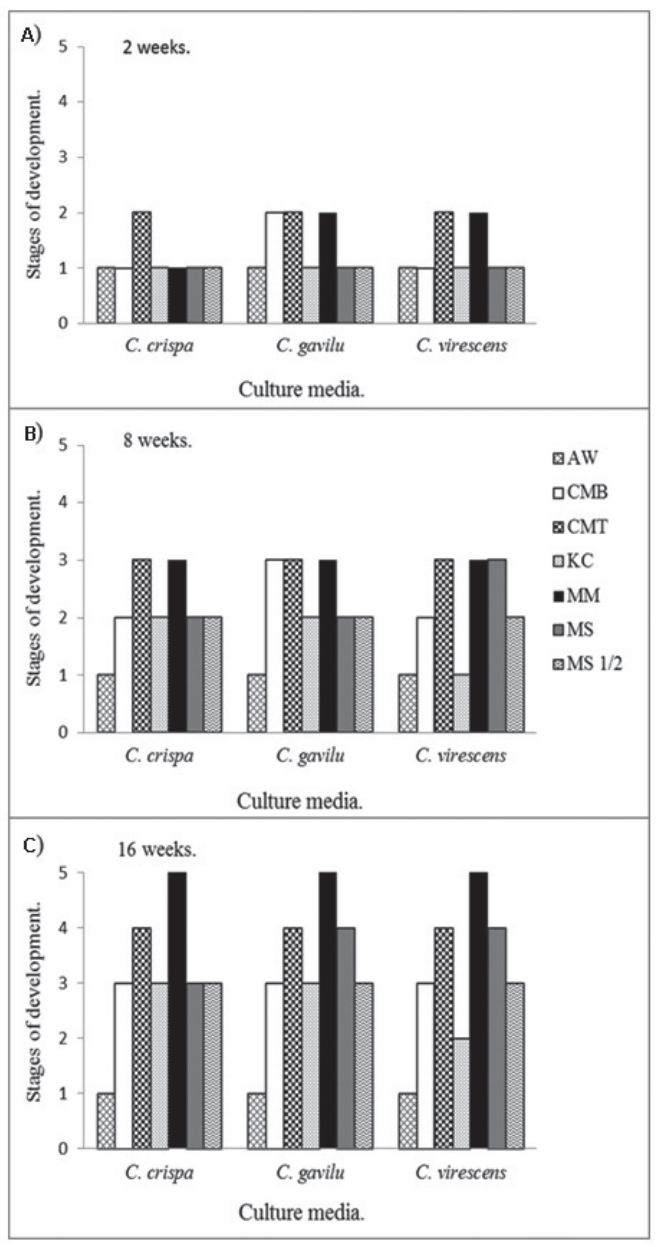

Figure 2. Developmental stages of seeds and embryos in three Chloraea species after 2 (A), 8 (B) and 16 weeks (C) of incubation in different culture media. AW: Agar Water. CMB: Banana Culture Medium. CMT: Tomato Culture Medium. KC: Knudson C. MM: Malmgren Modified terrestrial orchid medium. MS: Murashige and Skoog, and MS1/2: MS modified. Developmental stages follow a modified version of Yamazaki \& Miyochi (2006). / Estados de desarrollo de las semillas y embriones en tres especies de Chloraea luego de 2 (A), 8 (B) y 16 (C) semanas de incubación en diferentes medios de cultivo. AW: Agar Agua. CMB: Medio de Cultivo Banana. CMT: Medio de Cultivo Tomate. KC: Knudson C. MM: Medio Malmgren modificado para orquídeas terrestres. MS: Murashige y Skoog, y MS1/2: MS modificado. Los estados de desarrollo siguen una versión modificada de Yamazaki \& Miyochi (2006).

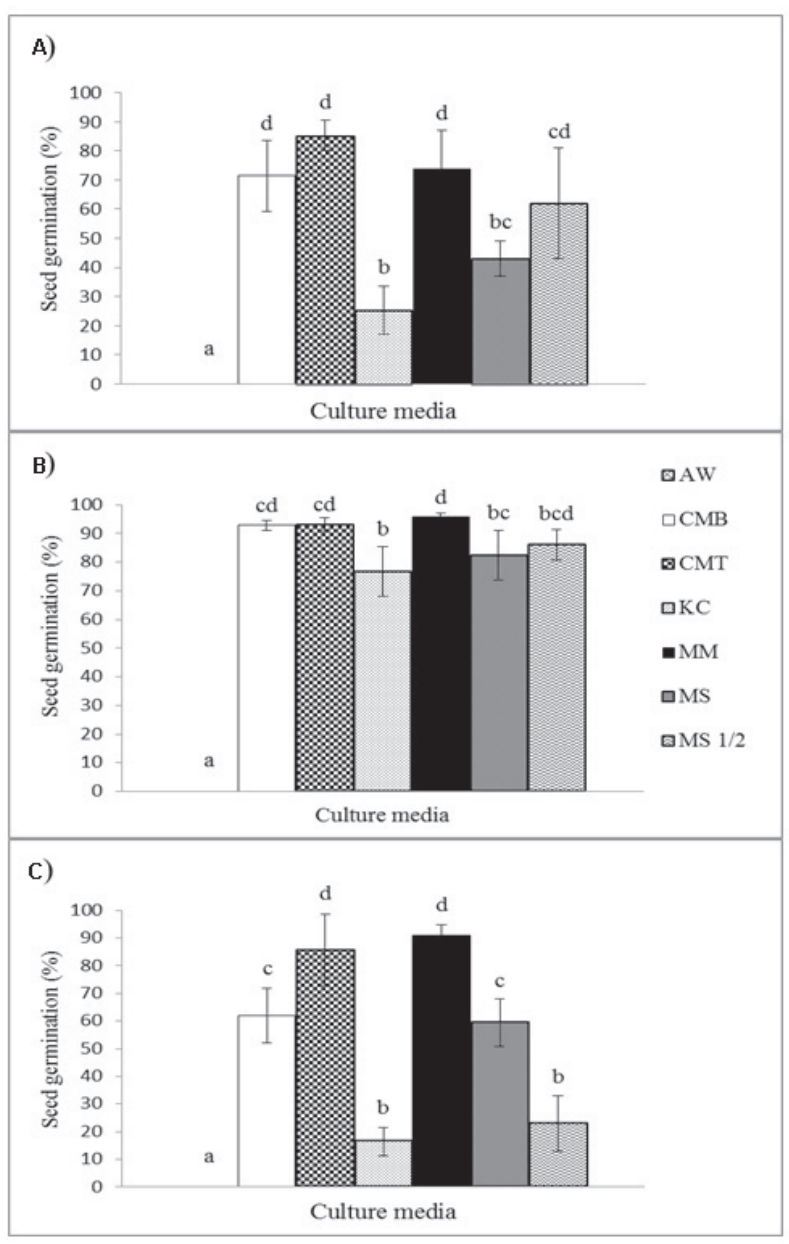

Figure 3. Average seed germination in C. crispa (A), C gavilu (B), and $C$. virescens $(\mathrm{C})$ after 16 weeks of incubation in different culture media. Different letters correspond to statistical differences (t-test, $\mathrm{p}<0.05$ ). AW: Agar Water. CMB: Banana Culture Medium. CMT: Tomato Culture Medium. KC: Knudson C. MM: Malmgren Modified terrestrial orchid medium. MS: Murashige \& Skoog, and MS1/2: MS modified. / Germinación promedio en C. crispa (A), C. gavilu (B) y C. virescens (C) luego de 16 semanas de incubación en diferentes medios de cultivo. Letras diferentes corresponden a diferencias estadísticamente significativas (test de $\mathrm{t}, \mathrm{p}<0.05$ ). AW: Agar Agua. CMB: Medio de Cultivo Banana. CMT: Medio de Cultivo Tomate. KC: Knudson C. MM: Medio Malmgren modificado para orquídeas terrestres. MS: Murashige y Skoog, y MS1/2: MS modificado. 


\section{DISCUSSION}

Many orchids are economically important (Dearnaley 2007, Dearnaley et al. 2012), mainly for their beautiful flowers which made them stand out among ornamental plants (Abraham et al. 2012). Chloraea and Gavilea are the most represented orchid genus in Chile (Elórtegui \& Novoa 2009, Novoa et al. 2015). The Chilean orchids Chloraea crispa, C. gavilu, and C. virescens have high ornamental value and potential as cut flowers. Thus, efficient propagation methods are required to propagate these species. In this study it was established that seeds of these orchid species can be asymbiotically germinated in laboratory conditions using different culture media. To our knowledge, asymbiotic (or symbiotic) germination for these species has not been previously reported. Studies on terrestrial temperate orchids are relatively scarce (but see Dixon 1991, Dutra et al. 2008, Steinford et al. 2010, Fracchia et al. 2014, Pereira et al. 2014, Atala et al. 2015) compared to studies on tropical species. Moreover, studies on orchid biology and asymbiotic reproduction of Chilean species are even rarer and for many species non-existent (but see Lehnebach \& Riveros 2003, Valdivia et al. 2010, Pereira et al. 2015). This is particularly important considering that many of those species are considered critically endangered (Novoa et al. 2006, Romero 2012). The shortage of ecological and functional studies on this group could be partially blamed on the lack of taxonomic knowledge in the country and the difficulties for the identification of the species in the field, especially individuals lacking reproductive structures. Currently, the only sources available for the identification of the species are out-of-date papers and divulgation books (Correa 1969, Novoa et al. 2006, Elórtegui \& Novoa 2009, Romero 2012).

In nature, orchids reproduce by seeds and depend on direct association with specific (to some degree) mycorrhizal fungi to germinate (Murguía \& Lee 2007, Pereira et al. 2005, Smith \& Read 2008, Valadares et al. 2012). As stated early, this dependency is due to the minimal amount, or even absence, of nutrients stored in the small seeds of orchids (Elórtequi \& Novoa 2009, Smith \& Read 2008, Abraham et al. 2012). The fungal partner supplies the required nutrients for embryo growth, nutrients that can also be supplied by specific culture media (Knudson 1946, Nadarajan et al. 2011, Pereira et al. 2015). The appropriate choice of nutrient medium seems to be crucial for seed germination and also for embryo development (Dutra et al. 2008, Rasmussen et al. 2015, Pereira et al. 2015). Seed germination varied among the studied Chloraea species depending on the used culture media. In C. crispa and C. virescens the highest germination (over $\sim 75 \%$ ) was achieved in CMT and MM. On the other hand, C. gavilu germinated over $75 \%$ in all tested culture media except AW. Previous studies on Bipinnula fimbriata reported a germination of 73 and $65.7 \%$ in MM and CMT, respectively (Pereira et al. 2015). Stewart \& Kane (2006) registered close to $89 \%$ asymbiotic seed germination of the terrestrial orchid Habenaria macroceratitis using Lindermann and Knudson C media after 7 weeks. However, in the same study MM medium was the only culture media that induced protocorm development to leaf-bearing after 16 weeks of incubation. More recent studies on the same orchid species reported asymbiotic germination percentages of $83.9 \%$ using $\mathrm{MM}$ medium, with embryos evidencing elongation of the first leaf after 21 weeks (Stewart \& Kane 2010). In our study, Knudson $\mathrm{C}$ media resulted in relatively low germination (below 30\%) in C. crispa and $C$. virescens. However, the same media resulted in over $70 \%$ germination in C. gavilu. These results reinforce the idea that interspecific differences in nutrient requirements exist, and specific protocols should be developed for each orchid species to be propagated. The ecological and physiological consequences of these differences should be addressed in future studies on temperate terrestrial orchids.

In terms of embryo development MM media showed the best results, evidencing the more advanced stage (stage 5 , shoot is differentiated from the protocorm) after 8 weeks compared to the other tested media. As mentioned above, the response of orchid seeds to different nutrient media varies between species (Nadarajan et al. 2011, Paul et al. 2011, Mohanty et al. 2012) and specific nutritional and environmental conditions are likely needed for in vitro germination of a determinate species (Arditti et al. 1990, Rasmussen 1995). The asymbiotic media used in this study varied greatly in mineral salt, nitrogen organic additives and vitamin compositions. For C. gavilu, all tested media (except for AW) supported a high germination, suggesting that this species is able to utilize a broad range of carbon and nitrogen forms and concentration. KC, MS and MS1/2 contain only inorganic sources of nitrogen (ammonium and nitrate). In contrast, MM (and probably CMB and CMT) contains only organic nitrogen sources, coinciding with the highest germination for $C$. crispa and C. virescens. Several researchers have reported that inorganic nitrogen may limit orchid germination, possibly due to low nitrate reductase activity during seed germination, and early protocorm development (Malmgren 1992, Van Waes \& Debergh 1986, Nadarajan et al. 2011). The high germination of $C$. gavilu in media with inorganic nitrogen sources could be explained by an early activation of nitrate reductase during germination and/or because organic nitrogen does not play an important role in seed germination as other nutrients or environmental factors, such as in the terrestrial orchid Bletia purpurea (Lam.) DC. (Dutra et al. 2008). In the field, C. gavilu shows a broad latitudinal distribution and can be found in diverse environments (Elórtegui \& Novoa 2009, Romero 2012, Novoa et al. 2015). In its wide geographical range it is likely that this species finds different nutrient, soil, and even biotic conditions, possibly explaining why 
is less demanding of specific nutrients and culture media in laboratory conditions. On the other hand, C. crispa and C. virescens have more narrow latitudinal distributions and more specific ecological conditions (Elórtegui \& Novoa 2009, Romero 2012, Novoa et al. 2015). Following the same argument used above, this could explain the higher selectiveness for Nitrogen sources and culture media.

In vitro germination of Chloraea species can shed light on possible in situ plant responses and their environmental requirements, and also further the knowledge of orchid development. This information can in turn be used to propagate plants for potential economic purposes and to establish better management policies for their in situ and ex situ conservation. In vitro methods can achieve high germination in these species, but the reintroduction of adult individuals in the field could likely need previous inoculation with species fungal partners to increase plant survival. Further studies are needed to confirm these still open questions.

\section{ACKNOWLEDGMENTS}

The present work was funded by project VRID-UdeC No. 214.418.006-1.0IN and DI-regular 037.446/2015 (PUCV).

\section{REFERENCES}

Abraham, S., Augustine, J., Thomas, T.D. 2012. Asymbiotic seed germination and in vitro conservation of Coelogyne nervosa A. Rhich. an endemic orchid to Western Ghats. Physiology and Molecular Biology of Plants 18(2): 245251.

Aggarwal, S., Zettler, L.W. 2010. Reintroduction of an endangered terrestrial orchid Dactylorhiza hatagirea (D. Don) Soo assisted by symbiotic seed germination: first report from the Indian subcontinent. Nature and Science 8(10): 139-145.

Arditti, J., Clements, M.A., Fast, G., Hadley, G., Nishimura, G., \& ERnst, R. 1982. Orchid seed germination and seedling culture. A manual. In: J. Arditti (ed.), Orchid biology. Reviews and perspectives II, pp. 243-370. Cornell University Press, Ithacha, NY, USA.

Arditti, J., Ernst, R., Yam, T.W., Glabe, C. 1990. A contribution of orchid mycorrhizal fungi to seed germination: a speculative review. Lindleyana 5: 249-255.

Atala, C., Muñoz-Tapia, L., Pereira, G., Romero, C., Vargas, R., Acuña-Rodríguez, I.S., Molina-Montenegro, M.A., BRITO, E. 2017. The effect of future climate change on the conservation of Chloraea disoides Lindl. (Orchidaceae) in Chile. Brazilian Journal of Botany 40(1): 353-360.

Atala, C., Pereira, G., Romero, C., Muñoz-Tapia, L., Vargas, R., Suz, L.M. 2015. Orchidiod fungi of the form-genus Rhizoctonia associated with the roots of Chloraea cuneata Lindl. From Araucanía, Chile. Gayana Botánica 72(1): 145-148.
Barbery, R., Molares, I. 2011. Manual para el cultivo in vitro de la orquídea Cattleya nobilior. Flor símbolo de Concepción. CEPAD, Editorial El País, Santa Cruz. 46 pp.

Bernhardt, P. 1995. Biogeography and floral evolution in the Geoblasteae (Orchidaceae). In: M.T.K. Arroyo, P.H. Zedler \& M.D. Fox (eds.), Ecology and biogeography of mediterranean ecosystems in Chile, California, and Australia, pp 116-134. Springer, Berlin, Germany.

Correa, M.N. 1969. Chloraea, género sudamericano de Orchidaceae. Darwiniana 15: 374-500.

Dearnaley, J.D. 2007. Further advances in orchid mycorrhizal research. Mycorrhiza 17: 475-486.

Dearnaley, J.D., Martos, F., Selosse, M.A. 2012. Orchid mycorrhizas: molecular ecology, physiology, evolution, and conservation aspects. In: B. Hock (ed.), Fulgal associations, $2^{\text {nd }}$ edn., pp. 207-230. Springer-Verlag, Berlin, Germany.

Dixon, K.W. 1991. Seeder/clonal concepts in Western Australian orchids. In: T.C.E. Wells \& J.H. Willems. (eds.), Population Ecology of Terrestrial Orchids, pp. 111-123. SPB Academic Publishing, The Hague, The Netherlands.

Dutra, D., Johnson, T., Kauth, P., Stewart, S., Kane, M., RICHARDSON, L. 2008. Asymbiotic seed germination, in vitro seedling development, and greenhouse acclimatization of the threatened terrestrial orchid Bletia purpurea. Plant Cell, Tissue and Organ Culture 94: 11-21.

Elórtegui, S., NovoA, P. 2009. Orquídeas de la Región de Valparaíso. Taller la Era, Viña del Mar. 83 pp.

Fracchia, S., Aranda-Rickert, A., Flachsland, E., Terada, G., SEDE, S. 2014. Mycorrhizal compatibility and symbiotic reproduction of Gavilea australis, an endangered terrestrial orchid from south Patagonia. Mycorrhiza 24: 627-634.

Heywood, V.H., Brummitt, R.K., Culham, A.Y., Seberg, O. 2007. Flowering Plant Families of the World. Firefly Books, Ontario. 424 pp.

Johnson, T., Stewart, S.L., Dutra, D., Kane, M.E., Richardson, L. 2007. Asymbiotic and symbiotic seed germination of Eulophia alta (Orchidaceae) preliminary evidence for the symbiotic culture advantage. Plant Cell, Tissue and Organ Culture 90: 313-323.

Kauth, P.J., Kane, M.E., Vendrame, W.A., Reinhardt-Adems, C. 2008. Asimbiotic germination response to photoperiod and nutritional media in six populations of Calopogon tuberosus var. tuberosus (Orchidaceae): evidence for ecotypic differentiation. Annals of Botany 102: 783-793.

Kauth, P.J., Vendrame, W.A., Kane, M.E. 2006. In vitro seed culture and seedling development of Calopogon tuberosus. Plant Cell, Tissue and Organ Culture 85: 91-102.

KNUDSON, L. 1922. Nonsymbiotic germination of orchid seeds. Botanical Gazette 73: 1-25.

KNUDSON, L. 1946. A new nutrient solution for germination of orchid seed. American Orchid Society Bulletin 15: 214-217.

Lehnebach, C.A. 2003. Preliminary checklist of the orchids of Chile. Botanical Journal of the Linnean Society 143: 449451.

Lehnebach, C., Riveros, M. 2003. Pollination biology of the Chilean endemic orchid Chloraea lamellata. Biodiversity and Conservation 12: 1741-1751.

Malmgren, S. 1992. Large-scale asymbiotic propagation of Cypripedium calceolus - plant physiology from a surgeon's 
point of view. Botanic Gardens Micropropagation News 1: 59-63.

Malmgren, S. 1996. Orchid propagation: theory and practice. In: C. Allen (ed.), North American native terrestrial orchids: propagation and production. Pp. 63-71. Maryland, North American Native Terrestrial Orchid Conference.

Mohanty, P., Paul, S., Das, M.C., Kumaria, S., Tandon, P. 2012. A simple and efficient protocol for the mass propagation of Cymbidium mastersii: an ornamental orchid of Northeast. India. AoB Plants 2012: pls023 doi:10.1093/aobpla/ pls023.

Murashige, T., Skoog, F. 1962. A revised medium for rapid growth and bioassays with tobacco tissue cultures. Physiologia Plantarum 15: 473-497.

Murguía, G.J., LeE, E.H. 2007. Manual de producción de orquídeas. Universidad Veracruzana, Xalapa, México. 75 pp.

Nadarajan, J., Wood, S., Marks, T.R., Seaton, P.T., Pritchard, H.W. 2011. Nutritional requirements for in vitro seed germination of 12 terrestrial, lithophytic and epiphytic orchids. Journal of Tropical Forest Science 23(2): 204-212.

Novoa, P., Espejo, J., Alarcón, D., Cisternas, M., Domínguez, E. 2015. Guía de campo de las orquídeas chilenas, segunda ed. ampliada. Ediciones Corporación Chilena de la Madera. Concepción. 240 pp.

Novoa, P., Espejo, J., Cisternas, M., Rubi, M., Domínguez, E. 2006. Guía de campo de las orquídeas chilenas. Ediciones Corporación Chilena de la Madera, Concepción. 120 pp.

Otero, J.T., BAYMAn, P. 2009. Germinación simbiótica y asimbiótica en semillas de orquídeas epífitas. Acta Agronomica 58(4): 270-276.

Paudel, M., Pradhan, S., Pant, B. 2012. In vitro seed germination and seedling development of Esmeralda clarkei Rchb.F. (Orchidaceae). Plant Tissue Culture \& Biotechnology 22(2): 107-111.

Paul, S., Kumaria, S., Tandon, P. 2011. An effective nutrient medium for asymbiotic seed germination and large scale in vitro regeneration of Dendrobium hookerianum, a threatened orchid of Northeast India. AoB Plants 2011: plr032 doi:10.1093/aobpla/plr032.

Pedersen, H.E., Rasmussen, H.N., Kahandawala, I.M., Fay, M.F. 2012. Genetic diversity, compatibility patterns and seed quality in isolated populations if Cypripedium calceolus (Orchidaceae). Conservation Genetics 13: 89-98.

Pereira, G., Albornoz, V., Muñoz-Tapia, L., Romero, C., Atala, C. 2015. Asymbiotic germination of Bipinnula fimbriata (Orchidaceae) seeds in different culture media. Seed Science and Technology 43(3): 1-11.

Pereira, G., Romero, C., Suz, L.M., Atala, C. 2014. Essential mycorrhizal partners of the endemic Chilean orchids Chloraea collicensis and C. gavilu. Flora 209: 95-99.

Pereira, O.L., Megumi, M.C., De Lima, C., Montandon, G. 2005. Isolamento e identificaçao de fungos micorrízicos rizoctonióides asociados a três espécies deorquídeas epífitas neotropicais no Brazil. Revista Brasileira de
Ciências do Solo 29: 191-197.

Rasmussen, H.N. 1995. Terrestrial Orchids: From Seed to Mycotrophic Plant. Cambridge University Press. Cambridge. 433 pp.

Rasmussen, H.N., Dixon, K.W., Jersakova, J., Tesitelova, T. 2015. Germination and seedling establishment in orchids: a complex of requirements. Annals of Botany 116: 391-402.

Reiche, C. 1910. Orchidaceae Chilenses. Anales del Museo Nacional de Santiago de Chile, Sección 2, Botánica 18: $1-88$.

Romero, C. 2012. Orquídeas de Nahuelbuta, Símbolo de la Comuna de Angol. Chile, Fondo de Protección Ambiental, Ministerio de Medioambiente, Gobierno de Chile. 80 pp.

Smith, S.E., Read, D.J. 2008. Mycorrhizal Symbiosis, 3rd edn. Academic Press, San Diego. 800 pp.

Steinfort, U., Verdugo, G., Besoain, X., Cisterna, M. 2010. Mycorrhizal association and symbiotic germination of the terrestrial orchid Bipinnula fimbriata (Poepp.) Johnst (Orchidaceae). Flora 205: 811-817.

StenberG, M.L., Kane, M.E. 1998. In vitro seed germination and green-house cultivation of Encyclia boothiana var. erythronioides, an endangered Florida Orchid. Lindleyana 13: 101-112.

Stewart, S.L., Kane. M.E. 2006. Asymbiotic germination and in vitro seedling development of Habenaria macroceratitis (Orchidaceae), a rare Florida terrestrial orchid. Plant Cell, Tissue and Organ Culture 86: 147-158.

Stewart, S.L., Kane, M.E. 2010. Effects of carbohydrate source on the in vitro asymbiotic seed germination of the terrestrial orchid Habenaria macroceratitis. Journal of Plant Nutrition 33: 1155-1165.

Thakur, U., Dongarwar, N. 2013. A new report of in vitro flowering and multiple shooting in a wild epiphytic orchid Oberonia recurva Lindl. from asymbiotically germinated seedling. Plant Knowledge Journal 2(3): 113-118.

Valadares, R.B., Pereira, M.C., Otero, J.T., Cardoso, E.J. 2012. Narrow fungal mycorrhzal diversity in a population of the orchid Coppensia doniana. Biotropica 44(1): 114-122.

Valdivia, C.E., Cisternas, M.A., Verdugo, S.G. 2010. Reproductive biology aspects of two species of Gavilea (Orchidaceae: Chloraeinae). Gayana Botánica 67: 44-51.

Van Waes, J.M., Debergh, P.C. 1986. In vitro germination of some Western European orchids. Physiologia Plantarum 67: 253-261.

YAmAZAKI, J., MiYoshi, K. 2006. In vitro asymbiotic germination of immature seed and formation of protocorm by Cephalanthera falcata (Orchidaceae). Annals of Botany 98: 1197-1206.

Zuloaga, F.O., Morrone, O., Belgrano, M.J. 2008. Catálogo de las Plantas Vasculares del Cono Sur (Argentina, Sur de Brasil, Chile, Paraguay y Uruguay). Monographs of the Missouri Botanical Garden 107, vol. 1. Pteridophyta, Gymnospermae, Monocotyledoneae. i-xcvi; 1-983.

Recibido: 05.01.2016

Aceptado: 24.10.2016 